\title{
ARTICLE
}

\section{Sighting patterns and habitat use of marine mammals at Guafo Island, Northern Chilean Patagonia during eleven austral summers}

Patrones de avistamientos y uso de hábitat de mamíferos marinos en Isla Guafo, Patagonia Norte de Chile, durante once veranos australes

\section{Mauricio Seguel ${ }^{1}$ and Héctor J. Pavés ${ }^{2 *}$}

${ }^{1}$ College of Veterinary Medicine, Department of Pathology, University of Georgia, Athens, Georgia, United States of America

${ }^{2}$ Departamento de Ciencias Básicas, Facultad de Ciencias, Universidad Santo Tomás, Los Carrera 753, Osorno, Chile.

*Corresponding author: hpaves@gmail.com, hectorpaveshe@santotomas.cl

\begin{abstract}
Resumen.- La ecorregión marina chiloense, en la Patagonia norte de Chile, es un punto de alta diversidad de mamíferos marinos, sin embargo, poco se conoce sobre sitios específicos utilizados por estas especies para la reproducción, lactancia, refugio y alimentación. Esta información es crítica para la planificación apropiada del uso del ecosistema y la conservación de los recursos marinos. Durante 11 veranos australes (2004-2008 y 2012-2017), se registró la presencia, distribución y comportamiento de 13 especies de mamíferos marinos en la Isla Guafo, una isla oceánica ubicada en el centro de la ecorregión chiloense. Isla Guafo es un importante sitio para la reproducción y alimentación del lobo fino austral (Arctocephalus australis australis), león marino sudamericano (Otaria byronia) y nutrias marinas (Lontra felina); para la alimentación, lactancia y tránsito de ballenas jorobadas (Megaptera novaeangliae), orcas (Orcinus orca) y ballenas azules (Balaenoptera musculus). Se registraron observaciones ocasionales de ballena de aleta (B. physalus), ballena franca austral (Eubalaena australis) y delfín austral (Lagenorhynchus australis). La zona costera también sirve como refugio para ejemplares del elefante marino del sur (Mirounga leonina) durante su muda y de descanso de un individuo del lobo fino subantárctico (Arctocephalus tropicalis). La información aquí presentada sitúa a Isla Guafo como una importante área de congregación, alimentación y reproducción de mamíferos marinos en Chile, varios de ellos amenazados. Debido a la creciente presión antropogénica en este ecosistema, se hace necesario contar con el diseño y la aplicación de planes y programas de protección y conservación formal de esta isla establecida como un sitio prioritario para la conservación marina en la Patagonia Norte de Chile.
\end{abstract}

Palabras clave: Mamíferos marinos, cetáceos, otaridos, Chiloé, Isla Guafo, Patagonia

Abstract.- The chiloense marine ecoregion, at the Northern Chilean Patagonia, has been considered a hotspot of marine mammal diversity, yet little is known regarding specific sites used by these species for reproduction, nursing, refuge, and foraging. This information is critical for proper spatial ecosystem planning and conservation of marine resources. In the austral summers of 2004 through 2008, and from 2012 to 2017, the presence, distribution, and behavior of 13 species of marine mammals was recorded at Guafo Island, an oceanic island located in the center of the chiloense ecoregion. Guafo Island is an important reproductive and feeding site for South American fur seals (Arctocephalus australis australis), South American sea lions (Otaria byronia) and marine otters (Lontra felina), and an important feeding, nursing, and transit location for humpback whales (Megaptera novaeangliae), Orcas (Orcinus orca), and blue whales (Balaenoptera musculus). We also recorded occasional sightings of fin whales (B. physalus), southern right whales (Eubalaena australis) and Peale's dolphins (Lagenorhynchus australis). The island coastline also serves as refuge for molting Southern elephant seals (Mirounga leonina) and vagrant Subantarctic fur seals (Arctocephalus tropicalis). The information presented here highlights Guafo Island as an important breeding, shelter, and feeding site for marine mammals in Chile. The growing anthropogenic pressure on this ecosystem emphasizes the importance of formal protection of this island as a priority site for marine conservation in the Northern Patagonia of Chile.

Key words: Marine mammals, cetaceans, otariids, Chiloé, Guafo Island, Patagonia 


\section{INTRODUCTION}

Marine mammals are essential components of the marine environment, acting as top predators and keystone species in food webs (Bowen 1997, Heithaus et al. 2008, Estes et al. 2009). Furthermore, whales are considered ecosystem engineers because their large biomass serves as habitat and energy source for other marine organisms (Roman et al. 2014). It is considered that extensive whaling in the past two centuries caused reduction of more than $90 \%$ of some whale populations, generating several changes in high latitude ecosystems, including misbalances in the food web that led to increased orca predation on fishes, sea otters, and pinnipeds (Springer et al. 2003, Baum \& Worm 2009, Estes et al. 2009, Ainley et al. 2010). The high sensitivity of marine mammals to changes in the abundance of other species and ocean productivity, make them excellent sentinels of marine environmental conditions (Gulland \& Hall 2007, Bossart 2011). For similar reasons, marine mammal distribution and habitat use are significant elements for spatial planning of marine ecosystems and design of marine protected areas (Outeiro et al. 2015). Because of this, substantial efforts have been devoted worldwide to the study of marine mammals as a tool to assess ecosystem stability, productivity, and health (Bossart 2011, Moore \& Gulland 2014, Thomas et al. 2016).

The chiloense ecoregion, in the Northern Chilean Patagonia, is an area historically recognized for its high marine productivity and diversity of marine vertebrates, including marine mammals (Hucke-Gaete et al. 2004, Quiroz 2014, Outeiro et al. 2015). This high productivity is due in part to the effects of the Humboldt and the Cape Horn Currents, which transport subantarctic Surface water into the southern Chilean channels and fjords (Silva et al. 1997, Palma \& Silva 2004, Longhurst 2007). These conditions have favored a very productive marine ecosystem that has been extensively exploited since the last century. For instance, during the modern whaling era, the most productive whaling stations in the southern Pacific Ocean were located in the chiloense ecoregion (Quiroz 2014).

Guafo Island $\left(43^{\circ} 35^{\prime} \mathrm{S} ; 74^{\circ} 42^{\prime} \mathrm{W}\right)$ is located in the middle of the chiloense ecoregion, and due to its distance from mainland has characteristics of an oceanic island (Fig. 1). Guafo Island waters have been historically known for the high abundance of large whales and other marine mammals, and in the early and mid- $20^{\text {th }}$ century the largest whaling station in the South Pacific operated in the northeast coast of the island (Quiroz 2014). Whaling records from 1936 indicate that large whales such as blue whales (Balaenoptera musculus Linnaeus, 1758), sperm whales (Physeter macrocephalus Linnaeus, 1758), fin whales (Balaenoptera physalus Linnaeus, 1758) and southern right whales (Eubalaena australis Desmoulins, 1822) were abundant in the Guafo Island waters. However, the presence of these cetaceans and other marine mammals is largely unreported in the $21^{\text {st }}$ century, even though, this information is critical to identify sites of importance for conservation of marine ecosystems (Outeiro et al. 2015). This article summarizes 11 years of marine mammal sightings at Guafo Island to: i) describe the species currently present, and ii) identify the importance of this area for the life history traits of each species (e.g., breeding, foraging, etc.).

\section{Materials ANd Methods}

During 11 austral summer seasons (2003-2008, 2012-2017, between November 15 th and March $\left.10^{\text {th }}\right)$ we documented the presence and habitat use (i.e., places for mating, foraging, movement, resting) of marine mammals from an observation point located at Punta Weather, Guafo Island (Fig. 1). This point is located between $20-50 \mathrm{~m}$ above sea level, allowing a $360^{\circ}$ view of the nearby coast. Scans and opportunistic observations were performed with the help of binoculars (Samsung 7-15×35 and 7×25), and covering all visible area within $5 \mathrm{~nm}$. Scan observations were performed for at least $10 \mathrm{~min}$ and repeated at least three times during each observation period (one per hour). Opportunistic observations were recorded during the entire study period. The daily observation time were on average $3 \mathrm{~h}$ during the morning (starting time between 07:00 and 09:00 h, and finalization time between 10:00 and 12:00 h), and other 3 hours in the afternoon (starting time between 16:00-17:00 h, finalization time between 19:00 and 20:00 h). Additionally, in 2004, 2005 and between 2012 and 2017, opportunistic navigation surveys were conducted onboard of different artisanal fishing boats, to the north ( $\mathrm{n}=10$ times, covering $11 \mathrm{~km}$ each time from Caleta Arrayán to Punta Weather), west ( $\mathrm{n}=5$ times, covering $17 \mathrm{~km}$ each time from Punta Weahter to Punta Sur), east ( $\mathrm{n}=10$ times, covering $16 \mathrm{~km}$ each time from Caleta Arrayán to Caleta Samuel), and south ( $\mathrm{n}=4$ times, covering $26 \mathrm{~km}$ each time from Caleta Samuel to Punta Sur) of the Guafo Island. Navigation trips were conducted in a single boat with two or three observers per trip. Marine mammals observed within $500 \mathrm{~m}$ of the navigation transect were recorded. Boat speed was constant (7-8 knots) and navigation was always conducted on Beaufort conditions $<3$ (wind speed $<10$ knots). Observations were performed with binoculars 


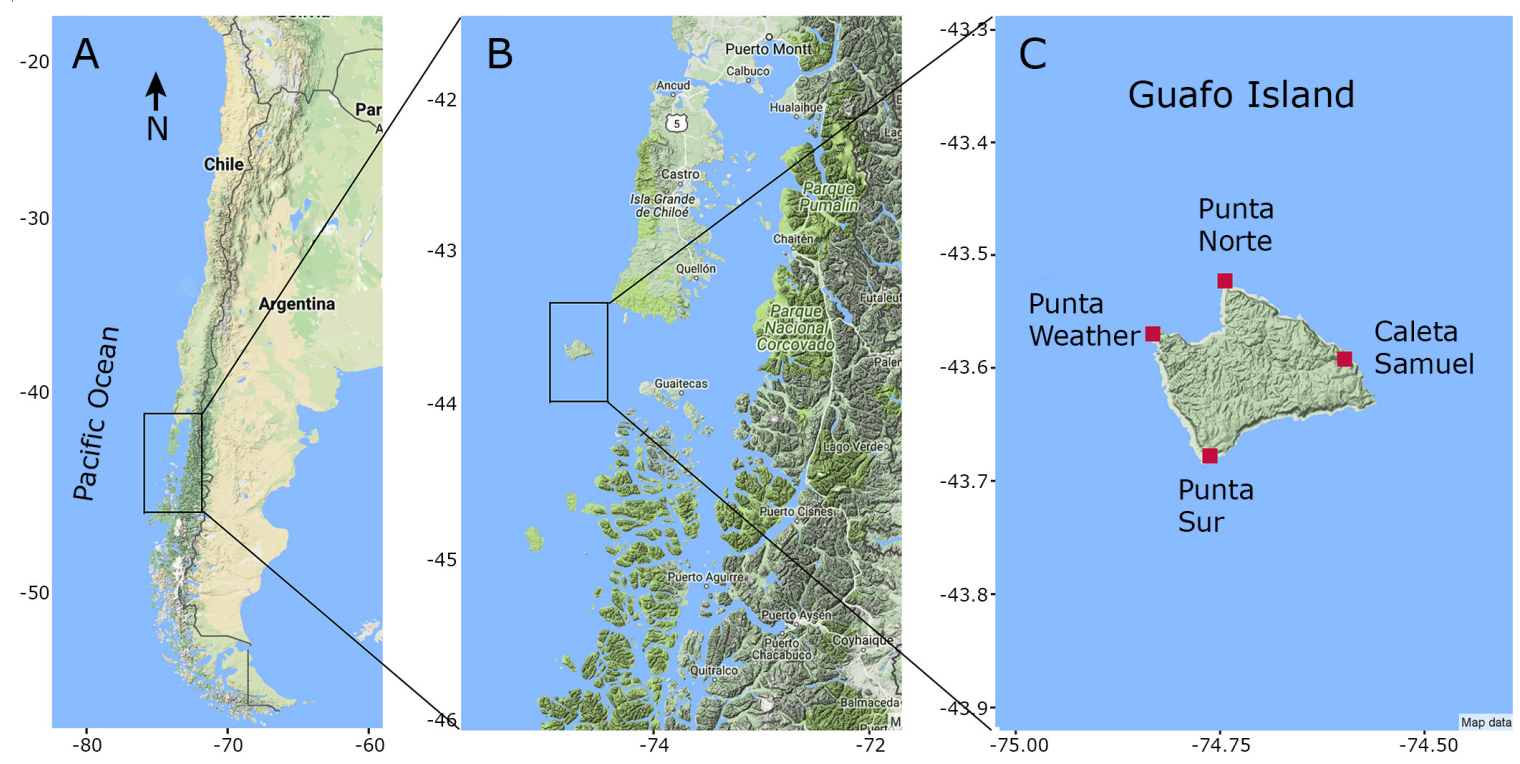

Figure 1. Location of Guafo Island within the chiloense marine ecoregion, Southern Chile. A) location of the chiloense ecoregion within Southern Chile is highlighted; B) a zoom of the chiloense ecoregion and the location of Guafo Island in the center of this ecomarine area is highlighted; C) Guafo Island map with the geographical references of the island (Punta Weather, Punta Norte, Punta Sur, Caleta Samuel) / Ubicación de Isla Guafo dentro de la ecorregión chiloense en el sur de Chile. A) se destaca la ubicación de la ecorregión chiloense dentro del sur de Chile; B) detalle de la ecorregión chiloense y la ubicación de Isla Guafo en el centro de esta ecorregión; C) mapa de Isla Guafo con las referencias geográficas de la isla (Punta Weather, Punta Norte, Punta Sur, Caleta Samuel)

$(10 \times 50)$ and using a 90 degrees visibility arch to the left and right of the boat bow (Tasker et al. 1984, Viddi et al. 2010). During the same period, artisanal fishermen that work at the extraction of red algae (Gigartina skottsbergii Setchell \& Gardner, 1936) on the island, were instructed to recognize whale blows, and asked to document through cellphone cameras any cetacean sighting during their normal activities in the island coast.

Along with the previously reported observations during 10 out of the 11 years monitored, land trips $(n=33)$ were performed from Caleta Arrayán to Caleta Toro, covering $22 \mathrm{~km}$ of coastline. During these trips all stranded animals (dead or alive) and congregations of marine mammals were recorded

Additionally, during the trips conducted on 2012, 2014 and 2015 a coastal land expedition was carried out through the north, east and south coasts of the island covering $30.4 \mathrm{~km}$ of coastline. In these expeditions, the presence of marine otters was specifically recorded through direct and indirect methods following previously described protocols (e.g., observation of individuals and footprints, samplings of feces; Medina-Vogel et al. 2006). The abundance of otariids and phocids was estimated using previously described methods (Pavés \& Schlatter 2008). The number of animals in each age class was recorded. Coastal sites were categorized as reproductive or nonreproductive based on the presence or absence of newborn pups, respectively. These observations were performed from all land observation sites (elevated points, land trips).

For all species identified, the information was condensed in a table recording the survey effort (when possible), species identified, number of animals, age classes observed, habitat use, date, and time according to methodology and categorizations previously described (Riedman 1990, Rivera 1990, Pavés et al. 2005, Pavés \& Schlatter 2008, Acevedo et al. 2011). The age classes established for cetaceans were: adults and calves, and for otariids and phocids: pups, juveniles, adult males, adult females. Cetacean calves were recognized by being less than $50 \%$ of their adult companion length. Habitat use was considered as the main use the animals gave during the observed period to the physical media they occupied (Hall et al. 1997), and was classified in the 
following major categories: foraging, mating, nursing, resting and travelling. For photographs and videos provided by local fishermen only the species, number of individuals, age class, and location were recorded. In some cases, the videos and consecutive good quality photographs also allowed for the identification of behavior or activity (e.g., foraging, mating).

Maps of marine mammal's distribution were constructed using the 'RGoogleMap' package for ' $\mathrm{R}$ 3.2.0' statistical software (Loecher \& Ropskin 2015). The number of sightings and the coordinates were used as input variables for the maps. The coordinates were estimated from the observation point employing relative distance y direction of the sightings. Then, the data was changed to coordinates in a cartographic map. When the sightings were made close to the observer, the coordinates were recorded through GPS. Similar maps were constructed to indicate sites of presence of marine otters and breeding colonies of South American sea lions and South American fur seals with the difference that, instead of number of sightings, the mean number of individuals recorded throughout the years was one of the input variables along with the geographic point coordinates.

\section{Results}

The sampling effort during the 11 summer seasons totalized 668 days of study, 2,064 h of observations, and $671 \mathrm{~km}$ of linear transects. During this period, 13 marine mammal species were observed at Guafo Island, including 8 cetaceans, 3 otariids, 1 phocid and 1 mustelid. The use of Guafo Island habitats was considered occasional for 6 species, breeding for 3 species, vagrant for 2 species, and as nursing and feeding grounds for a least 5 marine mammal species (Table 1).

\section{Cetaceans}

The most commonly observed cetacean species around Guafo Island was the humpback whale (Megaptera novaeangliae Borowski, 1781) with a total of 138 sightings (Table 1). All sightings were concentrated in the north coast of the island (Fig. 2). In 85 cases (62\%) a mothercalf pair was observed. The most common activity was travelling (78\%), followed by feeding (19\%) (Fig. 3a), whereas in some occasions the main activity was not recorded or undetermined (3\%). Also, jumping was recorded in $2 \%$ of the observation events. Among mysticetes, the second most common cetacean species

Table 1. Sightings and documentation of foraging, calves occurrence and conservation status of cetacean species identified at Guafo Island between 2003 and 2017 / Número de avistamientos realizados y, registros de uso de hábitat conductual de alimentación, presencia de crías y estado de conservación de las especies de cetáceos identificadas en Isla Guafo entre el 2003 y 2017

\begin{tabular}{|c|c|c|c|c|c|c|}
\hline Common name & Scientific name & $\begin{array}{l}\text { Number } \\
\text { observation } \\
\text { events }\end{array}$ & $\begin{array}{l}\text { Number } \\
\text { individuals/ } \\
\text { sighting }\end{array}$ & Foraging & $\begin{array}{l}\text { Presence } \\
\text { calves }\end{array}$ & $\begin{array}{c}\text { Conservation } \\
\text { status } \\
\text { (IUCN)* }\end{array}$ \\
\hline \multicolumn{7}{|l|}{ Mysticetes } \\
\hline Humpback whale & Megaptera novaeangliae & 138 & 1.63 & Yes & Yes $(n=85)$ & $\mathrm{LC}$ \\
\hline Blue whale & Balaenoptera musculus & 17 & 1.2 & Not observed & Yes $(n=1)$ & $\mathrm{EN}$ \\
\hline Fin whale & Balaenoptera physalus & 2 & 1.5 & Not observed & No & $\mathrm{EN}$ \\
\hline $\begin{array}{l}\text { Pacific Southern Right } \\
\text { whale }\end{array}$ & Eubalaena australis & 1 & 2 & Not observed & Yes $(n=1)$ & $\mathrm{CE}$ \\
\hline Sperm whale & Physeter macrocephalus & 1 & 1 & Not observed & No & VU \\
\hline \multicolumn{7}{|l|}{ Odontocetes } \\
\hline Orca & Orcinus orca & 24 & 3.2 & Yes & Yes $(n=8)$ & DD \\
\hline Bottlenose dolphin & Tursiops truncatus & 3 & 5 & Yes & No & $\mathrm{LC}$ \\
\hline Peale's dolphin & Lagenorhynchus australis & 2 & 5.5 & Not observed & No & DD \\
\hline
\end{tabular}

$\mathrm{LC}=$ Least concern, $\mathrm{EN}=$ Endangered, $\mathrm{CE}=$ Critically endangered, $\mathrm{VU}=$ Vulnerable, $\mathrm{DD}=$ Data deficient

* The IUCN Red List of Threatened Species. Version 2017-3. <www.iucnredlist.org> 

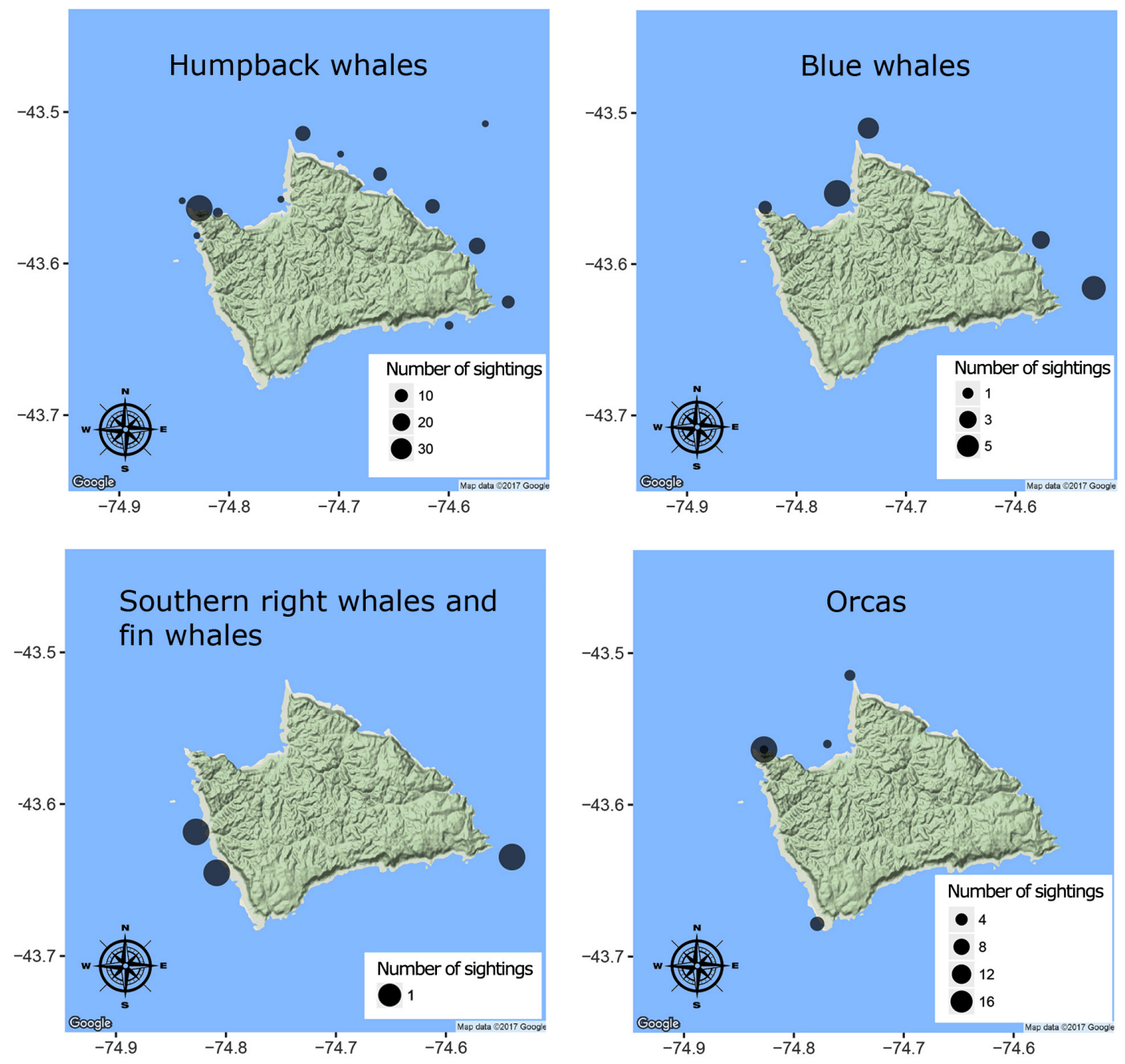

Figure 2. Distribution of humpback whales, blue whales, southern right and fin whales and orca sightings at waters around to Guafo Island between 2004-2008 and 2012-2017 / Distribución de los avistamientos de ballenas jorobadas, ballenas azules, ballenas franca austral y de aleta, y orcas en aguas adyacentes a Isla Guafo entre el 2004-2008 y 2012-2017

was the blue whale, with 17 (9.04\%) sightings. In this species, foraging was observed once and in only one occasion a mother-calf pair was observed. Sightings of fin whales were rare and restricted to the southeast coast of Guafo Island. In one occasion, on January 2006, a cowcalf pair of southern right whale was observed in the northwest coast of the island

The most common odontocete cetacean was the orca (Orcinus orca Linnaeus, 1758) with 26 sightings. Orcas were registered since 2013, and their presence was temporary with groups arriving as early as the second week of November and no sightings registered after the fourth week of December. In most sightings, there were at least 2 adult animals observed and in eight occasions $(32 \%)$ calves were also observed. Occurrence of orcas was restricted to areas close to South American fur seal (Arctocephalus australis australis Zimmermann, 1783) and South American sea lion (Otaria byronia Blainville, 1820 ) rookeries. In three occasions, groups of between 3 to 8 orcas were observed hunting South American fur seals ( $\mathrm{n}=2 ; 1$ adult female, 1 juvenile) or South American sea lions ( $\mathrm{n}=1 ; 1$ subadult male) (Fig. 3b). In one occasion, a small group of orcas were observed following a humpback whale cow-calf pair but close interaction or attacks were not documented, however the groups were only observed from land. 


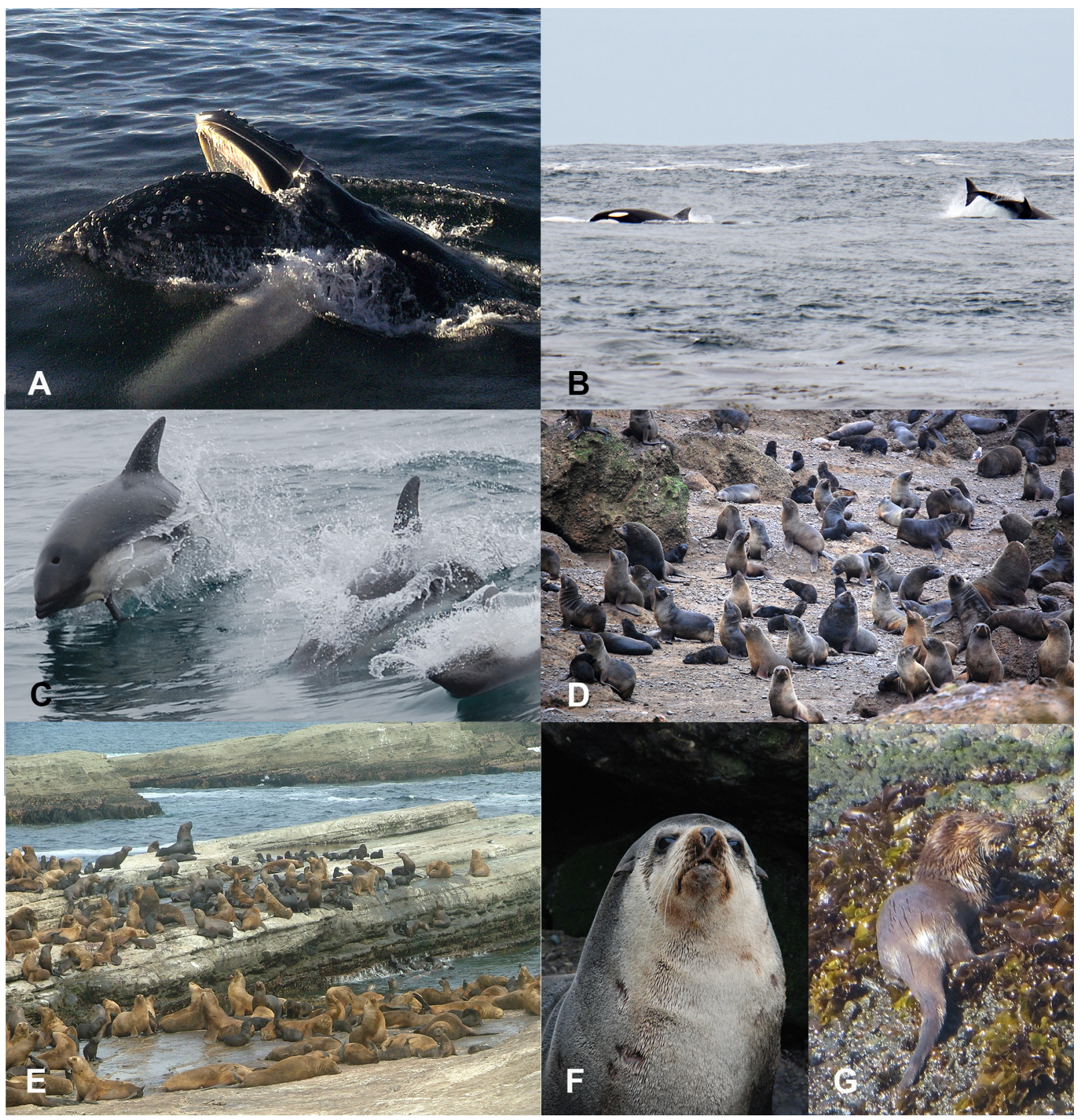

Figure 3. Marine mammals at Guafo Island. A) Humpback whale (M. novaeangliae) feeding in the northeast Coast of Guafo. B) Orcas ( $O$. orca) hunting next to fur seal (A. a. australis) breeding colony in the Punta Weather. C) Peale's dolphins (L. australis) in the northwest coast of Guafo Island. D) South American fur seal in the breeding rookery at Punta Weather. E) South American sea lion ( $O$. byronia) rookery at Punta Sur. F) Subadult male subantarctic fur seal (A. tropicalis) in the South American fur seal rookery. G) Marine otter (L. felina) feeding on fish in Guafo Island northwest coast. Photography credits: Raúl Oyarzun (A), Piero Becker (B), and Eugene DeRango (C) / Mamíferos marinos en Isla Guafo. A) Ballena jorobada ( $M$. novaeangliae) alimentándose en la costa noreste de Isla Guafo. B) Orcas (O. orca) cazando en aguas adyacentes a la colonia reproductiva de lobo fino austral (A. a. australis) en la Punta Weather de Isla Guafo. C) Delfínes australes (L. australis) en la costa noreste de Isla Guafo. D) Un sector de la colonia reproductiva de lobo fino austral en Isla Guafo. E) Colonia de león marino sudamericano (O. byronia) en Punta Sur. F) Macho subadulto del lobo fino subantártico (A. tropicalis) establecido en la colonia reproductiva del lobo fino austral. G) Chungungo (L. felina) alimentándose de peces en la costa noroeste de Isla Guafo 
Bottlenose dolphins (Tursiops truncatus Montagu, 1821) were observed in groups of 4 to 8 individuals. In one occasion, bottlenose dolphins were observed in Punta Weather swimming with fur seals while both species preyed on fish. Peale's dolphins (Lagenorhynchus australis Peale, 1984) were observed in a few occasions in groups of 4 to 8 individuals, usually exhibiting 'bowriding' behavior (Fig. 3c). In 2005, an adult carcass of a sperm whale with advanced postmortem changes was found in a sandy beach of the north coast of the island ('Caleta Rica' sector).

\section{Otaritids And Phocids}

Between 2004 and 2015, we registered a mean of 3,095 \pm 449.70 South American fur seals with a well-marked breeding structure (Table 2, Fig. 3d). South American fur seals were restricted to the Punta Weather (Fig. 3d). On the other hand, South American sea lions occupied several rocky flat platforms in the northwest and south coast of the island. However, the rookery with the highest sea lion abundance is located in Punta Sur (Fig. 3e, Fig. 4). This colony had a mean of 5,854 $\pm 3,912$ sea lions throughout the assessed summer seasons (Table 2).

Between December 2014 and the end of January 2015, a subadult male subantarctic fur seal (Arctocephalus tropicalis Gray, 1872) stayed in the South American fur seal rookery on Guafo Island (Fig. 3f) (Table 2). This individual occupied a peripheral zone of the rookery, next to the fur seal breeding area. The animal was in overall good body condition and had at least a few short foraging trips. Vocalizations and interactions with other adult or subadult South American fur seal males were common but mating or attempts of reproductive behavior with South American fur seal females were not observed.

In 2004, 2005, and from 2013 through 2017, 4 juveniles, 5 young males and 6 adult females of southern elephant seals (Mirounga leonina Linnaeus, 1758) were observed at several points of the west and south coast of Guafo Island (Table 2; Fig. 4). The individuals were resting or molting and stayed from 5 to 25 days in the island.

Table 2. Average number of pinnipeds at different locations of Guafo Island between 2004 and 2017 / Número promedio de pinnípedos observados en diferentes lugares de Isla Guafo entre el 2004-2017

\begin{tabular}{|c|c|c|c|c|c|c|c|c|}
\hline Species & Location & $\begin{array}{l}\mathrm{N}^{\circ} \text { adult } \\
\text { males }\end{array}$ & $\begin{array}{c}\mathrm{N}^{\circ} \\
\text { adults } \\
\text { females }\end{array}$ & $\begin{array}{c}\mathrm{N}^{\circ} \\
\text { Juveniles }\end{array}$ & $\begin{array}{l}\mathrm{N}^{\circ} \\
\text { Pups }\end{array}$ & $\begin{array}{l}\mathrm{N}^{\circ} \\
\text { Indet. }\end{array}$ & Total & Observations \\
\hline $\begin{array}{l}\text { South American fur seal } \\
\text { (Arctocephalus australis } \\
\text { australis) }\end{array}$ & Punta Weather & 258 & 1,629 & 29 & 1,134 & 45 & 3,095 & $\begin{array}{l}\text { Numbers correspond to the average for } \\
\text { seasons } 2004-2008 \text { and } 2013-2015\end{array}$ \\
\hline $\begin{array}{l}\text { South American sea lion } \\
\text { (Otaria byronia) }\end{array}$ & Punta Norte & 15 & 95 & 10 & 68 & 6 & 194 & $\begin{array}{l}\text { Average number of animals counted in } \\
2005-2007 \text { and } 2011\end{array}$ \\
\hline $\begin{array}{l}\text { South American sea lion } \\
\text { (Otaria byronia) }\end{array}$ & Caleta Toro & 10 & 60 & 29 & 0 & 2 & 121 & $\begin{array}{l}\text { Average number of animals counted in } \\
2005-2007 \text { and } 2012\end{array}$ \\
\hline $\begin{array}{l}\text { South American sea lion } \\
\text { (Otaria byronia) }\end{array}$ & Punta Weather & 17 & 31 & 15 & 14 & 4 & 81 & $\begin{array}{l}\text { Numbers correspond to the average for } \\
\text { seasons } 2004-2008 \text { and } 2013-2015\end{array}$ \\
\hline $\begin{array}{l}\text { South American sea lion } \\
\text { (Otaria byronia) }\end{array}$ & Puerto Laguna & 7 & 7 & 10 & 1 & 14 & 38 & $\begin{array}{l}\text { Average number of animals counted in } \\
2005-2007 \text { and } 2012\end{array}$ \\
\hline $\begin{array}{l}\text { South American sea lion } \\
\text { (Otaria byronia) }\end{array}$ & Punta Sur & 268 & 2,819 & 490 & 2,139 & 139 & 5,854 & $\begin{array}{l}\text { Average number of animals counted in } \\
2005-2006 \text { and } 2011 \text { (Oliva et al. 2012) }\end{array}$ \\
\hline $\begin{array}{l}\text { Subantarctic fur seal } \\
\text { (Arctocephalus tropicalis) }\end{array}$ & Punta Weather & 0 & 0 & 1 & 0 & 0 & 1 & $\begin{array}{l}1 \text { vagrant individual observed in 2014- } \\
2015\end{array}$ \\
\hline $\begin{array}{l}\text { Southern elephant seal } \\
\text { (Mirounga leonina) }\end{array}$ & Punta Weather & 2 & 4 & 2 & 0 & 0 & 8 & $\begin{array}{l}\text { Average number of animals between } \\
2005-2008 \text { and } 2012-2017\end{array}$ \\
\hline $\begin{array}{l}\text { Southern elephant seal } \\
\text { (Mirounga leonina) }\end{array}$ & Punta Sur & 3 & 2 & 2 & 0 & 0 & 7 & $\begin{array}{l}\text { Average number of animals between } \\
2004-2006\end{array}$ \\
\hline
\end{tabular}

$\mathrm{N}^{\circ}$ Indet. $=$ Number of animals of undetermined age class category 

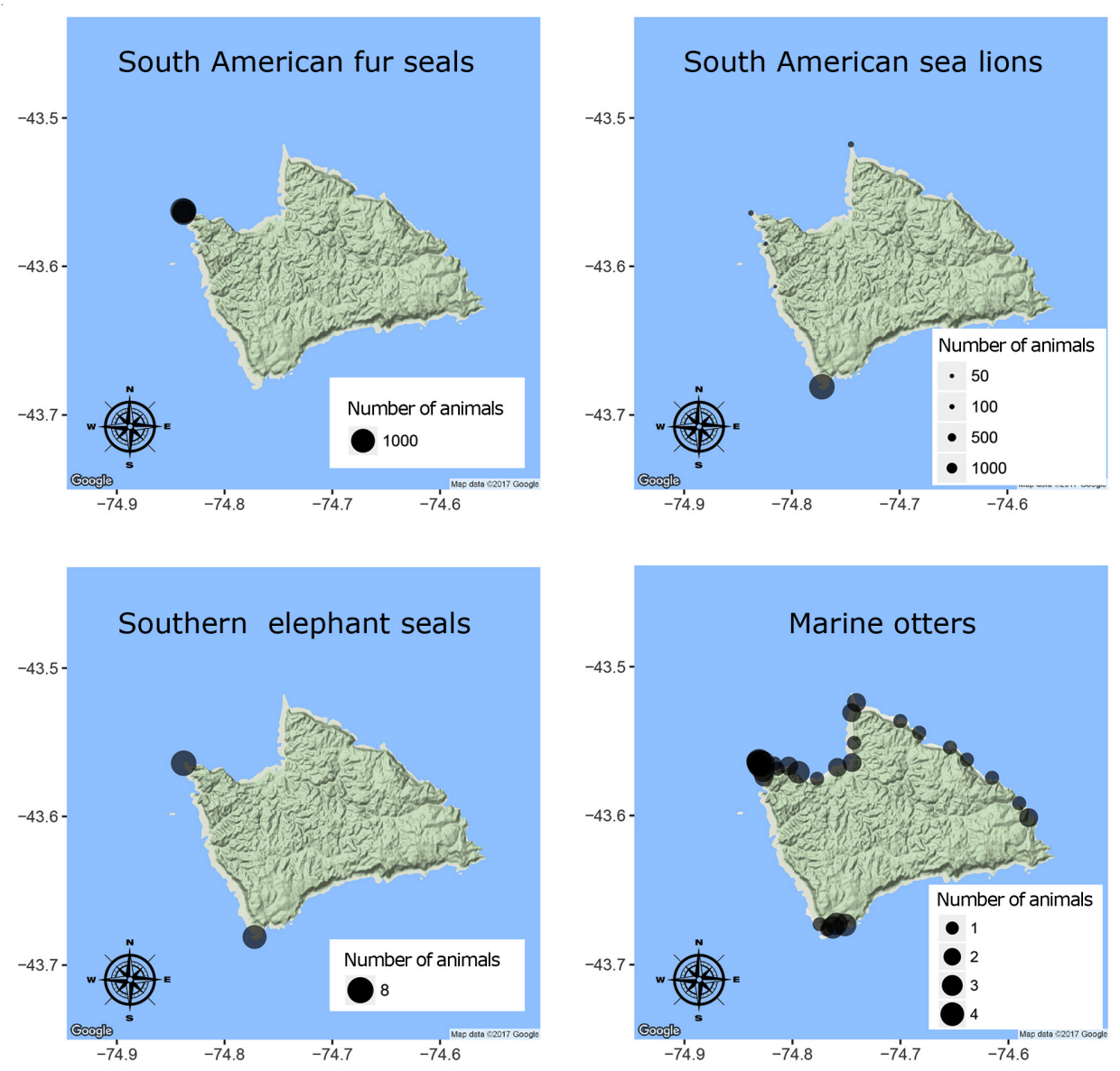

Figure 4. Distribution of pinnipeds and marine otters in Guafo Island, Northern Chilean Patagonia between 2004-2008 and 2012-2017 / Distribución de pinnípedos y chungungos en la Isla Guafo, Patagonia Norte de Chile entre el 2004-2008 y 2012-2017

\section{MARine OTters}

A total of 62 marine otters - Lontra felina (Molina, 1782) (44 adults, 18 pups) were recorded with a density of 2.0 otters $\mathrm{km}^{-1}$. However, in areas with predominant rocky substrate, which were usually shared with fur seals and in less extent with sea lions (northwest point of the island, Punta Weather), we recorded an average of 19 sea otters in $2.5 \mathrm{~km}$ of coastline, for a density of 7.6 otters $\mathrm{km}^{-1}$. Observed behaviors included feeding in 55 occasions $(60 \%)$ (Fig. $3 \mathrm{~g}$ ), traveling in 16 occasions $(17 \%)$, grooming/resting in 15 occasions (16\%) and mating in 6 occasions (7\%). In Punta Weather, there was a permanent family group of 2 adults and 1 or 2 juveniles throughout the years, with the presence of feeding and resting areas around the South American fur seal rookery.

\section{Discussion}

The 11 years of observational data indicate that Guafo Island waters and coastline serve as refuge, feeding and reproductive ground for at least 11 species of marine mammals, many of them classified as threatened, vulnerable or data deficient according to the IUCN Red List of 'Threatened Species'.

\section{Cetaceans}

Humpback whales were the most common cetacean observed at Guafo Island during the study period. This could be due to higher abundance of this whale species at Guafo Island, since sonographic studies on the abundance of cetaceans around the Guafo Island waters indicate that humpback whales are one of the most 
common species recorded (Dr. Laela Sayigh, 2017 pers. comm. $)^{1}$. Historic whaling records indicate that humpback whales were common in Guafo Island in the early $20^{\text {th }}$ century; however they were not caught as often as blue whales and fin whales (Quiroz 2014). This could indicate a lower abundance compared to rorqual species or a preference for larger whales by the early $20^{\text {th }}$ century whalers of Chiloé. However, we cannot preclude an observation bias, since most of our observations were performed from land, and this species tends to swim very close to the shore, facilitating sightings from observation points (Jefferson et al. 2015). However, our main observation site is elevated and open to the northwest, with an observational area of approximately $5 \mathrm{nmi}$, which could, in theory, increase the chances to see other whale species that swim farther from the shore.

During most of our humpback whale sightings, individuals were observed travelling or feeding. This is consistent with previous studies that propose the northern Pacific Patagonia as an important feeding site for humpback whales, being the northernmost feeding site known for this species in the Southern hemisphere (Hucke-Gaete et al. 2013). Additionally, we were able to detect some of the prey items in a few cases, which corresponded to crustaceans of the Euphausia sp. genus. These crustaceans are abundant in some areas of the chiloense ecoregion and are the main prey item of blue whales in the same area (Buchan \& Quiñones 2016). Therefore, it is likely that humpback and blue whales are attracted to Guafo Island waters because of the availability of food resources in the area.

The blue and the fin whale were also registered in Guafo Island surrounding waters. The blue whale population of the chiloense ecoregion correspond to a unique genetic pool the 'Chilean blue whale population' ${ }^{2}$ (Branch et al. 2007, Galletti-Vernazzani et al. 2017). Many aspects on the ecology of this population are unknown, but it is thought that correspond to a small group of between 570 to 760 whales that undergo seasonal migrations, and feed on the Corcovado Gulf in the Chiloé region during the austral summer (Galletti-Vernazzani et al. 2017). Our sightings expand the knowledge regarding the habitat used by these whales in the chiloense ecoregion, because in previous studies, the sea around Guafo Island has not been as intensely surveyed as channels and the western coast of Chiloé Island (HuckeGaete et al. 2004, Galletti-Vernazzani et al. 2012, 2017). Historical records suggest that blue whales and fin whales were very abundant near Guafo Island in the past century. For instance, between 1931 and 1935, 72 blue whales and 132 fin whales were killed in Guafo Island waters (Quiroz 2014). The low number of fin whales registered during our study period suggests that fin whales are less abundant at Guafo Island than previous the modern whaling era. For large long living mammals, recovery of populations can take several decades (Torres-Florez et al. 2014), and currently very little is known regarding the distribution and ecology of fin whales in the Northern Chilean Patagonia.

The Southern right whale was registered in only one occasion during the study period, which is probably related to the small size of this whale population. Reilly et al. (2013) and Galletti-Vernazzani et al. (2014) mention that the Chile-Peru subpopulation of the Southern right whale is critically endangered, with approximately 50 individuals left in the southeastern Pacific Ocean. Therefore, the fact that we recorded a mother-calf pair is very significant.

The most common odontocete cetacean was the orca. Orcas are a cosmopolitan species, yet there are marked differences in the morphology and ecology of different populations throughout the world (Taylor et al. 2013). Very little is known regarding orcas inhabiting the northern Chilean Patagonia. Recent studies have shown that orcas are more common in the Chilean Patagonia than previously thought (Häussermann et al. 2013a, b). Similar to previous studies in other parts of the Patagonia (Häussermann et al. $2013 \mathrm{a}, \mathrm{b})$, orcas at Guafo Island prey on marine mammals such as South American sea lions and South American fur seals. This probably explains why sightings were more common in areas close to these otariid rookeries. Additionally, the preference of these prey species could explain why orcas showed a temporary presence at Guafo Island, since the period when they are

\footnotetext{
${ }^{1}$ Research Specialist Biology, Woods Hole Oceanographic Institution, 266 Woods Hole Rd. MS\# 50, Woods Hole, MA 02543-1050, Office Phone: +1 508289 2977, Isayigh@whoi.edu

${ }^{2}$ Committee on Taxonomy. List of marine mammal species and subspecies. Society for Marine Mammalogy <www.marinemammalscience.org >
} 
observed is when otariid pups are weaned and leave the rookery. Therefore, these young marine mammals could represent an easy prey for orcas. Other potential food sources for orcas at Guafo Island are the calves of baleen whales. Orcas have been found to prey on sei whales in the Chilean Patagonia (Häussermann et al. 2013a), and in at least one occasion we observed a group of orcas following a humpback whale mother-calf pair, but predation attempts were not observed. However, the behavior of orcas and humpback whales could not be followed for the whole period of interaction, because these observations were made from land.

Bottlenose and Peale's dolphins were observed in a few occasions in the island. Although foraging behavior was observed only in bottlenose dolphins, it is very likely that Peale's dolphins use this area to forage as well. The Guafo Island coastline is rich in kelp forests, which is one of the preferred environments where Peale's dolphins find their prey (Viddi et al. 2010). Although Peale's dolphins were not very common at Guafo Island, it is one of the most commonly observed cetaceans in inner water and channels of the chiloense ecoregion (Viddi et al. 2010). Additionally, its acrobatic behavior in front of vessels facilitates its observation. It is possible that the oceanic nature of Guafo Island limit their distribution in the nearby waters since this species prefer habitat with more complex barometry and currents (Viddi et al. 2010).

A stranded sperm whale was observed in 2005 in the north Coast of Guafo Island. This large odontocete is more pelagic than the other cetaceans recorded (Jefferson et al. 2015), and the lack of sightings in the water could be due to the lack of more pelagic surveys in our investigations as most vessel trips were conducted in waters within the continental plate. On the other hand, this stranded animal could have died far from Guafo Island waters and not correspond to a common cetacean in pelagic areas near Guafo Island.

\section{Otariids And Phocids}

South American fur seals and South American sea lions are the most abundant otariid species at Guafo Island, with important breeding rookeries in two sites; Punta Weather and Punta Sur. For South American fur seals, the number of pups born each year on Guafo Island $(\sim 1500)$ can be considered significant for the estimated number of South American fur seals in Peru and Chile (approximately 40,000, Cárdenas-Alayza et al. 2016a).
Additionally, the total number of fur seals reported in our study $(\sim 3,200)$ could be underestimated because of the observation bias of terrestrial censuses. For instance, Oliva et al. (2012), report for the same Guafo Island rookery numbers close to 6,000 animals during the summer. Therefore, considering the numbers reported in our study and those published in aerial censuses, Guafo Island represents an important breeding colony for this species in the eastern South Pacific Ocean (Pavés 2008).

South American fur seals have a discontinuous distribution in the south Atlantic and south Pacific Oceans, and are included in the least concern conservation category of the IUCN (Cárdenas-Alayza et al. 2016a, Pavés et al. 2016). However, South American fur seal populations in the eastern South Pacific Ocean experienced a decline close to $60 \%$ in the last decade of the $20^{\text {th }}$ century, being the cause of this decline unknown as well as the current population trends (Venegas et al. 2002, Pavés 2008, Cárdenas-Alayza et al. 2016a). Guafo Island fur seal population represent the last point of expansion of the western South Atlantic fur seals into the Pacific Ocean, which probably occurred more than 10,000 years ago before the last glaciation (Túnez et al. 2013, Crespo et al. 2015, Rodrigues et al. 2018). However, the genetic structure of Guafo Island fur seals also differs from the western South Atlantic populations (Crespo et al. 2015, Rodrigues et al. 2018), therefore Guafo Island is a strategic point for management of this subspecies and its conservation, as it represents unique genetic diversity, which has probably been favored by local adaptations to the southern Pacific Ocean conditions (Rodrigues et al. 2018).

Compared to fur seals, South American sea lions have a more continuous distribution in South America and they are concentrated in larger numbers in the eastern South Pacific Ocean. The total population of this species in Chile is estimated to be 197,000 individuals (Cárdenas-Alayza et al. 2016b) and the areas that include Guafo Island population (Los Lagos Region) harbor approximately 25\% of the Chilean population of South American sea lions (Oliva et al. 2012, Cárdenas-Alayza et al. 2016b). Therefore, the number of animals in Guafo Island (approximately 6,000) represent the second largest reproductive colony of this species in 'Los Lagos Region' after Metalqui Island ( 23,000; Oliva et al. 2012), and one of the most important in southern Chile along with the Guamblin Island rookery $(\sim 11,000$ animals, Oliva et al. 2012). 
The coexistence of important populations of these two otariids species in Guafo Island is probably related to the different coastal habitats that the island provides. Sea lions prefer flat rocky platforms and beaches for breeding (Pavés et al. 2005), which are more common in the south point of the island, while fur seals prefer areas with large clasts, steep creeks, caves, and high altitude hills for breeding and nursing (Pavés \& Schlatter 2008). These conditions are more common in the northwest point of Guafo Island, where the fur seal rookery is located.

The presence of a vagrant subantarctic fur seal in 2015 is interesting since to the best of our knowledge, is the first record of this species in the chiloense ecoregion. Vagrant individuals of this fur seal are common and reported in several oceans given the circumpolar distribution of the species (Jefferson et al. 2015). Guafo Island serves as refuge and resting point for many pelagic and/or vagrant marine mammals' species, probably due to its oceanic nature. This could also be the case of Southern elephant seals, which use the island flat rocky platforms for resting and molting regularly. Southern elephant seals have a circumpolar distribution with most reproductive colonies located northern to the Antarctic sea ice pack (Jefferson et al. 2015). This species spend long periods feeding in the ocean and only approach land twice a year, in one occasion for breeding and in the other for molting. During molting, elephant seals change most of their fur and need a safe place to rest for approximately 20 to 30 days (Slip et al. 1992). Guafo Island serves this function regularly for this species.

\section{MARINe OTTERS}

Marine otters are endangered and their current distribution is discontinuous along the Peruvian and Chilean coast (Valqui 2012, Valqui \& Rheingantz 2015). This species depends heavily on coastal and intertidal ecosystems, preferring habitat open to tidal waves with rocky shores (Medina-Vogel et al. 2006). The northwest point of the Guafo Island gathers these conditions, and consequently concentrates the highest density of marine otters in the island. In the nearby Chiloé Island, densities of up to 6.9 observable otters $\mathrm{km}^{-1}$ have been found, and were though until now to be the highest abundance reported for this species (Medina-Vogel et al. 2006, Valqui 2012). Therefore, our findings highlight the importance of the northwest coast of Guafo Island for this endangered otter species. Additionally, the considerable distance of Guafo Island from other coastal ecosystems has led to a significant genetic differentiation of Guafo Island marine otters, which represent one of the six significant management conservation units for the species, highlighting the importance of this population (Vianna et al. 2010).

In conclusion, Guafo Island is an important breeding, foraging, and/or shelter site for several endangered marine mammal species. Historical and present records indicate that this strategic point within the chiloense ecoregion is a site of high diversity and abundance of marine mammal species. Currently, Guafo Island forests and surrounding waters lack any formal protection or implementation of management measures. The increasing demand for exploitation of marine coastal and pelagic ecosystems for aquaculture and/or extractive large scale fishing, jeopardize sites as Guafo Island, which in the past have suffered the adverse consequences of lack of management. Our 10-plus years of field research highlight the urgent need for legal protection of Guafo Island marine ecosystems in order to maintain the high diversity and abundance of marine mammal species reported in this manuscript.

\section{ACKNOWLEDGEMENTS}

We appreciate the logistical support of the Chilean Navy through the fifth naval zone Commander in chief and head of naval operations. We thank the support and friendship of the Chilean Navy administration on maritime traffic at Puerto Montt and the Chilean Navy Guafo Island lighthouse crews. We appreciate the significant contributions of artisanal fishermen of Quellón (Vessel crews: Fresia del Carmen, Marimar II, Marimar III, Matias Jesus, Mayra-Denisse and Nautylus V). We thank the abnegate field assistance of Diego Miranda, Pamela Núñez, Andrea Nadeau, Paula Antileo, Carola Valencia, Diego Perez-Venegas, Francisco Muñoz, Eugene DeRango, Piero Becker and Josefina Gutierrez. We appreciate the comments, revision and language edition of Dr Nicole Gottdenker (The University of Georgia) on this manuscript, and the information discussed with Dr. Laela Sayigh (Woods Hole Oceanographic Institution). This work was supported by The Rufford Small Grant Foundation (Grant N 13225-1), Morris Animal Foundation (Grant N D16ZO-413) and the Society for Marine Mammalogy Small Grants in aid of research (SG-2005, SG2011, SG-2015 and SG-2016). HJP was supported by Institute of Zoology-Universidad Austral de Chile (UACH), Dirección de Investigación y Desarrollo of 
UACH (DID-D-2004-7/D- 2005-15/UACh S-2013-19), MECESUP Doctorate Program (AUS0111 y UCO0214), Vicerrectoría de Investigación y Postgrado de la Universidad Santo Tomás (UST 2015-2016/23) and the Postdoctorate Program 2011 - FONDECYT No. 3120100. Work conducted under permits of the Undersecretariat for Fisheries and Aquaculture (SUBPESCA) (Res. Ex. N 976, 2016), and Institutional animal use and care committee of the University of Georgia (Project ID A2013 11-004-Y3A0). This work is dedicated to the memory of our mentor, Dr. Roberto Schlatter (1944-2016), a scientist that contributed to the conservation of wildlife in Chile and Guafo Island.

\section{LITERATURE CITED}

Acevedo J, K Rasmussen, F Felix, C Castro, M Llano, E Secchi, N Saborio, A Aguayo-Lobo, B Haase, M Scheidat, L Dalla-Rosa, C Olavarria, P Forestell, P Acuña, G Kaufman \& LA Pastene. 2007. Migratory destinations of humpback whales from the Magellan Strait feeding ground, southeast Pacific. Marine Mammal Science 23(2): 453-463.

Ainley D, G Ballard, L Blight, S Ackley, S Emslie, A Lescroël, S Olmastroni, S Townsend, C Tynan, $P$ Wilson \& E Woehler. 2010. Impacts of cetaceans on the structure of Southern Ocean food webs. Marine Mammal Science 26: 482-498.

Baum JK \& B Worm. 2009. Cascading top-down effects of changing oceanic predator abundances. Journal of Animal Ecology 78(4): 699-714.

Bossart GD. 2011. Marine mammals as sentinel species for oceans and human health. Veterinary Pathology 48(3): 676690.

Bowen WD. 1997. Role of marine mammals in aquatic ecosystems. Marine Ecology Progress Series 158(1): 267274.

Branch TA, EMN Abubaker, S Mkango \& DS Butterworth. 2007. Separating southern blue whale subspecies based on length frequencies of sexually mature females. Marine Mammal Science 23: 803-833.

Buchan SJ \& RA Quiñones. 2016. First insights into the oceanographic characteristics of a blue whale feeding ground in northern Patagonia, Chile. Marine Ecology Progress Series 554: 183-199.

Cárdenas-Alayza S, L Oliveira \& E Crespo. 2016a. Arctocephalus australis. The IUCN Red List of Threatened Species 2016: e.T2055A45223529. <http://dx.doi.org/ 10.2305/IUCN.UK.2016-1.RLTS.T2055A45223529.en>

Cárdenas-Alayza S, E Crespo \& L Oliveira. 2016b. Otaria byronia. The IUCN Red List of Threatened Species 2016: e.T41665A61948292. <http://dx.doi.org/10.2305/ IUCN.UK.2016-1.RLTS.T41665A61948292.en>
Crespo EA, ACM Schiavini, NA García, V Franco-Trecu, RNP Goodall, D Rodríguez, J Stenghel \& LR de Oliveira. 2015. Status, population trend and genetic structure of South American fur seals, Arctocephalus australis, in southwestern Atlantic waters. Marine Mammal Science 31(3): 866-890.

Estes JA, DF Doak, AM Springer \& TM Williams. 2009. Causes and consequences of marine mammal population declines in southwest Alaska: a food-web perspective. Philosophical Transactions of the Royal Society B: Biological Sciences 364(1524): 1647-1658.

Galletti-Vernazzani B, CA Carlson, E Cabrera \& RL Brownell. 2012. Chilean blue whales off isla Grande de Chiloe, 2004-2010: Distribution, site-fidelity and behaviour. Journal of Cetacean Research and Management 12(3): 353360 .

Galletti-Vernazzani B, E Cabrera \& RL Brownell. 2014. Eastern South Pacific southern right whale photoidentification catalog reveals behavior and habitat use patterns. Marine Mammal Science 30(1): 389-398.

Galletti-Vernazzani B, JA Jackson, E Cabrera, CA Carlson \& RL Brownell. 2017. Estimates of abundance and trend of Chilean blue whales off isla de Chiloé, Chile. Plos One 12: e0168646.<https://doi.org/10.1371/journal.pone.0168646>

Gulland FMD \& AJ Hall. 2007. Is marine mammal health deteriorating? Trends in the global reporting of marine mammal disease. EcoHealth 4(2): 135-150.

Häussermann V, G Försterra \& E Plotnek. 2013a. Sightings of marine mammals and birds in the Comau Fjord, Northern Patagonia, between 2003 and mid 2012. Spixiana 36: 113144.

Häussermann V, J Acevedo, G Försterra, M Bailey \& A Aguayo-Lobo. 2013b. Killer whales in Chilean Patagonia: additional sightings, behavioural observations, and individual identifications. Revista de Biología Marina y Oceanografía 48(1): 73-85.

Heithaus MR, A Frid, AJ Wirsing \& B Worm. 2008. Predicting ecological consequences of marine top predator declines. Trends in Ecology and Evolution 23(4): 202-210.

Hucke-Gaete R, LP Osman, CA Moreno, KP Findlay \& DK Ljungblad. 2004. Discovery of a blue whale feeding and nursing ground in southern Chile. Proceedings of the Royal Society B: Biological Sciences 271(Suppl. 4): S170-S173.

Hucke-Gaete R, D Haro, JP Torres-Florez, Y Montecinos, F Viddi, L Bedriñana-Romano, MF Nery \& J Ruiz. 2013. A historical feeding ground for humpback whales in the eastern South Pacific revisited: The case of Northern Patagonia, Chile. Aquatic Conservation: Marine and Freshwater Ecosystems 23(6): 858-867.

Jefferson TA, MA Webber \& RL Pitman. 2015. Marine mammals of the world: a comprehensive guide to their identification, 608 pp. Academic Press, San Diego. 
Loecher M \& K Ropkins. 2015. RgoogleMaps and loa: Unleashing $\mathrm{R}$ graphics power on map tiles. Journal of Statistical Software 63(4): 1-18.

Longhurst AR. 2007. Ecological geography of the sea, 527 pp. Academic Press, San Diego.

Mangel JC, T Whitty, G Medina-Vogel, J Alfaro-Shigueto, C Cáceres \& BJ Godley. 2011. Latitudinal variation in diet and patterns of human interaction in the marine otter. Marine Mammal Science 27(2): 14-25.

Medina-Vogel G, JL Bartheld, RA Pacheco \& CD Rodríguez. 2006. Population assessment and habitat use by marine otter Lontra felina in southern Chile. Wildlife Biology 12(2): 191-199.

Moore SE \& FMD Gulland. 2014. Linking marine mammal and ocean health in the 'New Normal' Arctic. Ocean and Coastal Management 102: 55-57.

Oliva D, M Sepúlveda, LR Durán, A Urra, W Sielfeld, R Moraga, G Pavés \& L Muñoz. 2012. Cuantificación poblacional de lobos marinos en las Regiones X -XI y propuesta de escenarios de manejo. Informe Final Proyecto FAP ID 4728-46- LP11: 1-100. <http://metadatos.mma.gob.cl/ sinia/Censo XIV X XI.pdf $>$

Outeiro L, V Haussermann, F Viddi, R Hucke-Gaete, G Forsterra, H Oyarzo, K Kosiel \& S Villasante. 2015. Using ecosystem services mapping for marine spatial planning in southern Chile under scenario assessment. Ecosystem Services 16: 341-353.

Palma S \& N Silva. 2004. Distribution of siphonophores, chaetognaths, euphausiids and oceanographic conditions in the fjords and channels of southern Chile. Deep-Sea Research Part II: Topical Studies in Oceanography 51(69): 513-535.

Pavés H. 2008. Conducta reproductiva, mortalidad neonatal y tendencia poblacional de una agrupación reproductiva del lobo fino austral (Arctocephalus australis, Zimmermann, 1783) en la isla Guafo, Chiloé, Chile. Tesis de Grado, Doctorado en Ciencias, mención Sistemática y Ecología, Facultad de Ciencias, Universidad Austral de Chile, Valdivia, $198 \mathrm{pp}$.

Pavés HJ \& RP Schlatter. 2008. Temporada reproductiva del lobo fino austral, Arctocephalus australis (Zimmerman, 1783) en la isla Guafo, Chiloé, Chile. Revista Chilena de Historia Natural 81(1): 137-149.

Pavés HJ, RP Schlatter \& CI Espinoza. 2005. Patrones reproductivos del lobo marino común, Otaria flavescens (Shaw 1800), en el centro-sur de Chile. Revista Chilena de Historia Natural 78(4): 127-146.

Pavés H, R Schlatter, V Franco-Trecu, E Páez, W Sielfeld, V Araos, LM Batallés \& L Cappozzo. 2016. Breeding season of the South American fur seal (Arctocephalus australis gracilis): New data to establish independent evolutionary histories. Revista de Biología Marina y Oceanografía 51(2): 241-253.
Quiroz D. 2014. Etnografía histórica de la planta ballenera en isla Guafo [1921-1937]. Magallania 42(2): 81-107.

Reilly SB, JL Bannister, PB Best, M Brown, RL Brownell Jr, DS Butterworth, PJ Clapham, J Cooke, GP Donovan, J Urbán \& AN Zerbini. 2013. Eubalaena australis (Chile-Peru subpopulation). The IUCN Red List of Threatened Species 2013: e.T133704A44231477.<http:/ / d x . do i . org/ 10.2305 / I U C N. UK. 2013 1.RLTS.T133704A44231477.en>

Rodrigues P, M Seguel, J Gutierrez, H Pavés, C Verdugo. 2018. Genetic connectivity of the South American fur seal (Arctocephalus australis) across Atlantic and Pacific oceans revealed by mitochondrial genes. Aquatic Conservation: Marine and Freshwater Ecosystems 28: 315-323.

Roman J, JA Estes, L Morissette, C Smith, D Costa, J McCarthy, JB Nation, S Nicol, A Pershing \& J Smetacek. 2014. Whales as marine ecosystem engineers. Frontiers in Ecology and the Environment 12(7): 377-385.

Silva N, C Calvete \& H Sievers. 1997. Características oceanográficas físicas y químicas de canales australes chilenos entre Puerto Montt y Laguna San Rafael (Crucero CIMAR-Fiordo 1). Ciencia y Tecnología del Mar 20: 23106.

Slip DJ, NJ Gales \& HR Burton. 1992. Body mass loss, utilisation of blubber and fat, and energetic requirements of male southern elephant seals, Mirounga leonina, during the moulting fast. Australian Journal of Zoology 40(3): 235-243.

Springer AM, JA Estes, GB van Vliet, TM Williams, DF Doak, EM Danner \& B Pfister. 2003. Sequential megafaunal collapse in the North Pacific Ocean: An ongoing legacy of industrial whaling? Proceedings of the National Academy of Sciences of the United States 100(21): 1222312228.

Taylor BL, R Baird, J Barlow, SM Dawson, J Ford, JG Mead, G Notarbartolo di Sciara, P Wade \& RL Pitman. 2013. Orcinus orca. The IUCN Red List of Threatened Species 2013: e.T15421A44220470.<http://dx.doi.org/ 10.2305/IUCN.UK.2013-1.RLTS.T15421A44220470.en>

Thomas PO, RR Reeves \& RL Brownell. 2016. Status of the world's baleen whales. Marine Mammal Science 32(2): 682734.

Torres-Florez JP, R Hucke-Gaete, H Rosenbaum \& CC Figueroa. 2014. High genetic diversity in a small population: The case of Chilean blue whales. Ecology and Evolution 4(8): 1398-1412.

Túnez J, H Cappozzo, H Pavés, D Albareda \& M Cassini. 2013. The role of Pleistocene glaciations in shaping the genetic structure of South American fur seals (Arctocephalus australis). New Zealand Journal of Marine and Freshwater Research 47(2): 139-152. 
Valqui J. 2012. The marine otter Lontra felina (Molina, 1782): A review of its present status and implications for future conservation. Mammalian Biology 77(2): 75-83.

Valqui J \& ML Rheingantz. 2015. Lontra felina. The IUCN Red List of Threatened Species 20152015: e.T12303A21937779. <http://dx.doi.org/10.2305/ IUCN.UK.20152.RLTS.T12303A21937779.en>

Venegas C, J Gibbons, A Aguayo, W Sielfeld, J Acevedo, N Amado, J Capella, G Guzmán \& C Valenzuela. 2002. Distribución y abundancia de lobos marinos (Pinnipedia: Otariidae) en la región de Magallanes, Chile. Anales del Instituto de la Patagonia 30: 67-82.
Vianna J, P Ayerdi, G Medina-Vogel, JC Mangel, H Zeballos, M Apaza \& S Faugeron. 2010. Phylogeography of the marine otter (Lontra felina): Historical and contemporary factors determining its distribution. Journal of Heredity 101(6): 676-689.

Viddi F, J Torres-Flores \& S Ribeiro. 2010. Spatial and seasonal variability in cetacean distribution in the fjords of northern Patagonian, Chile. TT- Spatial and seasonal variability in cetacean distribution in the fjords of northern Patagonian Chile. Journal of Marine Science 67: 959-970.

Received 18 August 2017 and accepted 29 June 2018

Associate Editor: Maritza Sepúlveda M. 